\title{
Relationship between Authoritative Parenting Style and Preschool's Prosocial Behavior
}

\author{
Nurul Arifiyanti ${ }^{凶}$ \\ Pendidikan Islam Anak Usia Dini, STAINU Purworejo
}

\begin{abstract}
Preschool's behavior must be developed since early of children ages. It is believed to affects their further characters. It plays an important role in their habit, building interaction, and character development. Children's behavior is influenced by the habit which is done by the people around of them, like parent. Hence this study proposes parenting style on preschool's prosocial behavior. Those effects are likely varied from home. Participating preschool students $(\mathrm{N}=61)$ during two weeks in January 2017 who had a mean age of 5.14 years. The data were obtained using questionnaire and observation sheet. A quantitative research method was use to collection, analysis and interpretation of data. Sig. $=0.251$ show that there is no significant relation between authoritative parenting style and preschool prosocial behavior. It can be concluded that there were alternative factors such as teacher-classmates, teacher-child relation, and children's moods and feelings. Prosocial behavior is important for children in their connection with peers. Based on the present study result, it can be suggested that teacher also have proportion to develop prosocial behavior.
\end{abstract}

Keywords: authoritative parenting style, parents, preschool, prosocial behavior

\begin{abstract}
Abstrak
Perilaku anak harus distimulus sejak usia dini. Hal ini dapat mempengaruhi karakter mereka yang akan mempengaruhi sikap, cara berinteraksi, dan perkembangan karakter. Perilaku anak dipengaruhi oleh pembiasaan yang diterapkan oleh orang-orang di sekitarnya. Oleh karena itu, penelitian ini mengkaji pengaruh gaya pengasuhan terhadp perilaku prososial anak, terutama dari rumah. Penelitian ini melibatkan anak prasekolah $(\mathrm{N}=61)$ selama dua minggu pada bulan Januari 2017 dengan rerata usia 5.14 tahun. Data dikumpulkna melalui kuisioner dan lembar pengamatan. metode kuantitatif digunakan untuk pengumpulan, analisis, dan interpretasi data. Hasil menunjukkan Sig.= 0.251 yang berarti tidak ada hubungan yang signifikan antara gaya pengasuhan autoritatif dan perilaku prososial anak. Hubungan guru dan teman sebaya, guru dengan anak, dan situasi psikologis anak menjadi beberapa faktor yang berpengaruh. Penting bagi anak untuk memiliki sikap prososial agar ia dapat diterima di kelompok sebayanya. Oleh karena itu, guru juga memiliki peran untuk megnembangkan sikap prososial anak.
\end{abstract}

Kata Kunci: gaya pengasuhan autoritatif; orang tu; anak usia dini; perilaku prososial anak

Copyright (c) 2019 Nurul Arifiyanti

$\triangle$ Corresponding author :

Address : Alamat penulis

ISSN 2356-1327 (Media Cetak)

Email : nurularifiy@gmail.com

ISSN 2549-8959 (Media Online) 


\section{INTRODUCTION}

The authoritative parenting enable a family may adopt negotiated approached to manage behavior in the belief that young children need authoritative guidance with this aspect of learning as with any other (Dowling, 2014). Family members must demonstrate consistent and reasonable expectations about how to behave; it is easier child to respond. This helps young children to understand how to try to control their behavior. Moreover, in an easy and loving relationship young children will want to behave in a way which pleases the adults who care for them. Adults can support young preschooler's development by building their trust, communicating with them, getting down on their level, using music tool to communicate with them, staying close to them, and being careful not to over stimulate. Parent, family, and teacher are the closest community for young children. These will give direct and be modeling for children to develop selfregulation.

Self-regulation refers to ability to regulate or control one's impulses, behavior, and emotions until an appropriate time, place, or object is available for expression (Berns, 2010). Self-regulation becomes an important thing for children to be accepted in social community. This can be shaped since in early year when growth and development is moving fast. Preschooler is special subject that growing and developing fast in early years. Not only the cognitive but also the self-regulation is important for their basic life. One of selfregulation indicator is children show the prosocial behavior when they on the playground or in classroom.

The term prosocial behavior typically refers to a large class of voluntary behaviors that share the common intention to benefit another (Dunfield \& Kuhlmeier,
2013). Usually, preschooler in kindergarten can have prosocial behavior without asked by teacher. They want sharing or giving help because the close relationship with another. But it don't getting loose from the habit that their environment give to always build good relation with another. A wealth of studies shows that prosocial behavior is linked to various aspects of positive youth development including academic success (Lai, Siu, \& Shek, 2015). It matches with Vygotsky theory about cognitive development (Santrock, 2007). According to Vygotsky children develop concept which is systematic, logic, and rationale as the effect of communicating with the more competent people. It can be their peer or old man. So, another people and language hold the most important role in child's development. This can be disturbed it if they fail to build an interaction. He also believed that social contact leads young children to adopt the values and behavior that they observed in daily life (Dowling, 2014). Hence, they must have appropriate behavior to be involved in socialization process.

Displays of prosocial behavior also have been related positively to other socially competent outcomes, including social acceptance and approval among classmates and being liked by teachers. Children who like sharing and helping peers are more liked than children who are not respect. But, even prosocial behavior first become evident in children of about 2 or 3 at about interest in playing with other children arises (Boyd \& Bee,2009) not all children do like that. It also depends on their mood and feeling. When another peer gives help, he or she may be angry. He want do all the activity by him.

Bovey \& Strain stated that in early childhood settings, children have difficulty sharing, inviting and including others in play, and being kind (Hannon, 2015). A 
child maybe has difficulties, but the other maybe easily can make a friendship. It all depend on how when they at home, parent give an example and give them large opportunities to share and know others. The children often said something that hurt each other such as "you are not my friend." Also there are fights because of toys sharing and role playing with fighting like what they had been watched on television. If the children can't keep themselves on this fight role playing, they will hurt the other and encourage the affray each another. One of the aims of socialization is to teach developmental skill which includes getting along with the others (Berns, 2010). To build socialization, child has to cooperate, share, and help others when needed. Early children can start to learn this from their family.

The way of young children interact with the peers may influence their peers to accept (Biddle, Nevarez, Henderson, \& Kerrick, 2014). Prosocial behavior can impact the child's development through social interaction. Learning behavior can be started from home within helped by parents. Then, it can be continued when children get to preschool. Therefore, this will discuss about relationship between authoritative parenting style and preschool's prosocial behavior.

\section{Prosocial Behavior}

Prosocial behaviors are behavior or actions that good for another person but do not necessarily benefit the person who emits the actions (Biddle, Nevarez, Henderson, \& Kerrick, 2014). Prosocial behavior benefits others and demonstrates the presence of a social conscience. Young children may first behave prosocially by sharing a toy or by patting a friend on the when the friend is hurt. Prosocial behavior such as sharing and showing empathy are important indicators of emotional and social competency. In contrast, a lack of prosocial behavior in young children is associated with mental health problems that will extend to another positive behavior

Prosocial responses such as cooperating, sharing, giving comfort, and offering to help, become increasingly apparent throughout childhood as children develop cognitively and have more social interactions (Eisenberg \& Fabes, 1998; Berns, 2004). Prosocial behavior doesn't just automatically occur by putting children in group and setting limits. Egocentricity of preschool age children kept them from seeing another person's perspective (Mena \& Eyer, 2001). Egocentrism mean children can't take other's perspective; they just understand their own point of view. Egocentricity of preschooler, age 3-6, begin to become less and exhibit altruistic acts if they also benefit to their self ("I'll share so you'll be my friend"). School-agers, age 6 to 12 , who can take the role of others, understand the meaning needs of others ('I'll help you because you can't do it by yourself) (Berns, 2010). Children strive to structure and understand relationship occurring in the environment around them, their effort can be limited by their egocentrism. Donaldson has reported that children do not egocentrism when they do task which are relevant to their last experience (Sunal, 1990.

The concept of this focuses on three critical elements; they are cooperation, empathy, and altruism (Miller, 2010). Cooperation is working or doing together and unselfishly toward a common goal. At least, there are two children or more to do something together. The variety of cooperative learning deemphasizes student achievement and concentrate on group performance. Before make a cooperative learning, children can make decision or promise with his friends as a mean of fostering positive peer interaction. This also 
helps children to build their capability to generate an idea. Empathy is feeling and understands what other's feel. It makes the children have insight into their thoughts and actions. Altruism refers to behavior that is kind, considerate, generous, and helpful to others that have consistency over time. This behavior begins to appear during the preschool years (in some children, it appears by age two) (Berns, 2004).

Prosocial behavior that include on social competency is affected by some factors (Biddle, Nevarez, Henderson, \& Kerrick, 2014). The factors are parents, peers, culture, and teachers. These have large effect not only in social competency but also in all aspects of children's live. Parent can influence this skill toward both mother and father with indirect monitoring. Indirect monitoring is keeping a watchful eye on the children while they are interacting or playing with the peers. Parents just intervene when the situation is not comfort. When children have interaction with peers, they not only learn about academically but also socially. They share the last experience or story about favorite film, resolve conflict, and imitate the other peer to share the snacks or toys. Children behave in what ways that reflect the values of their individual's culture. Children from minority in a mix culture classroom may be seem don't have social competence to build interaction with the majority. They maybe feel uncomfortable, shy, and withdraw. Hence, teacher has to have more creative thinking to manage the best class environment so the children can build more relationship with the others.

\section{Authoritative Parenting Style}

Home is the first place for a child to learn about behavior. Young children start to find out what they are allowed to do, what is accepted behavior and what is not. They observe parent's behavior to be a model for them. Then, they try to do same even can create another behavior that can be positive or negative. In early infancy, children are dependent on older family members (Dowling, 2014). In practice, emotions such as fatigue, anger, and love will sometimes hijack the best though-out strategies. However, although a young child will learn a lot through simply observing family conduct, he will learn a great deal more if he is helped to understand it. Parent's approach is also often influenced by memories of how they were brought up. Young mothers may admit to hearing themselves repeat what their mothers said when responding to their own children.

Parenting style is a concept aimed at describing how parents treat their children across two broad dimensions: responsiveness and demandingness (Biddle, Nevarez, Henderson, \& Kerrick, 2014). Responsiveness (also referred to as parental warmth or supportiveness) is how sensitive, supportive, and acquiescent parents are to children's needs and demands. Demandingness (also referred to behavioral control) refers to how much parents insist that their children obey family rules and act in mature way, how strictly parents supervise and discipline their children, and how willing parents are to confront children who disobey.

Authoritative parenting style is characterized by warm relation with children and open communication (Holden, 2010), acceptance, respect for and encouragement of the child's autonomy, and discipline through the setting of reasonable limits on the child's behavior and the use of reasoning and induction (Muhtadie, Zhou, Eisenberg, \& Wang, 2013). Parent try to start asking anything about what children have done that day. And if the children make mistake or have a problem they try to discuss it with the children. They also set and enforce clear the 
reasonable, rule limits, and use supportive disciplinary methods rather than punishment. This parenting style will give outcomes for children to have high cognitive and social competence in the middle childhood. When in the adolescence, children will have high selfesteem, excellent social, skill, strong prosocial concern, and high academic achievement. Baumrind found that authoritative parenting, which includes nurturance, communication, firm control, and maturity demands, best predicts children well-being- at least in the most Western cultures (Scarlett, Ponte, Singh, 2009).

The authoritative parenting enable a family may adopt negotiated approached to manage behavior in the belief that young children need authoritative guidance with this aspect of learning as with any other (Dowling, 2014). Dunn's studies suggest that in families where arguments are followed by discussion about what went wrong and resolutions, all of this helps a young child to grasp moral. They explain the reasons for rules and offer loving support to help children achieve it. Family members must demonstrate consistent and reasonable expectations about how to behave; it is easier child to respond. This helps young children to understand how to try to control their behavior. Moreover, in an easy and loving relationship young children will want to behave in a way which pleases the adults who care for them. Adults can support young preschooler's development by building their trust, communicating with them, getting down on their level, using music tool to communicate with them, staying close to them, and being careful not to over stimulate. Preparing the environment and understanding their developmental level are important.
Early childhood is a special time in life (Miller, 2010). They like play and explore everything which is around them. Environment and last experience can be the source of cognitive and behavior learning such as social environment. Social environment is one of their best teachers to develop. These environments both can accept and refuse them because it depend on behave. Children needs appropriate attitude so the social can accept them. Hence, children must capable the prosocial behavior. Prosocial behavior is needed by children to build interaction and socialization with others.

Prosocial behavior is showed with cooperating, sharing, giving comfort, and offering to help from a child to another child. This can't be work when egocentrism kept them in their own perspective. With warm relationship between childrenparents, it would be less. Children will understand why prosocial behavior has to be done. It not just for helping, but it can easy them to be accepted in social environment which will promote their development in all aspect.

(Knafo \& Plomin, 2006) found that both genetic and environmental effects prosocial behavior. One of the environmental factor are parenting style. Scholar has attempted to investigate the relations among dimensions of parenting styles, sympathy, prosocial moral reasoning, and prosocial behaviors (Carlo, Mestre, Samper, Tur, \& Armenta, 2011). It is suggest that parental warmth, sympathy, and prosocial moral reasoning were predictive of prosocial behaviors. Based on the existing literature, it was hypothesized that there is relationship between authoritative parenting style and preschool's prosocial behavior. 


\section{METHODOLOGY}

The subjects were 61 preschooler (age 4-6 years) and their parents from Yasmin Muadz bin Jabbal preschool located in Yogyakarta, Indonesia. They were equally divided by sex and age: 9 boys and 6 girls aged 4 years; 14 boys and 8 girls aged 5 ; and 10 boys and 14 girls aged 6 years (mean $=5.14)$. They were contacted through their schools. Information about sex and age was taken from the school records.

Data were collected by observation and questionnaire. Researcher observed the prosocial behavior at classroom with observation sheet, and give then questionnaire to the parents. The authoritative parenting style's indicator which has been used to arrange questionnaire are shown on Table 1 below. This is from Parenting Practice Questionnaire Construct by Robinson, Mandleco, Olsen, \& Hart (1995).

Table 1. Authoritative Parenting Style's Indicator

\begin{tabular}{|c|c|c|}
\hline Variable & Aspect & Indicator \\
\hline $\begin{array}{l}\text { Authoritative } \\
\text { parenting } \\
\text { style }\end{array}$ & Demand & $\begin{array}{l}\text { a. Giving warmth } \\
\text { attitude to child } \\
\text { b. Supporting all } \\
\text { child's want } \\
\text { a. Giving } \\
\text { appropriate } \\
\text { attitude advice } \\
\text { b. Giving firmness if } \\
\text { the child breaks } \\
\text { the rule. } \\
\text { c. Controlling } \\
\text { child's behavior } \\
\text { d. Disciplining child } \\
\text { e. Discussing a } \\
\text { problem with the } \\
\text { child } \\
\text { f. Looking for } \\
\text { problem's } \\
\text { solution together } \\
\text { with child. }\end{array}$ \\
\hline
\end{tabular}

Further, the preschooler's prosocial behavior that is affected by parenting style has been divide into some specific variables for valid and authentic measurement. The variables are sharing snacks with friends, sharing toys, caring to hurt friends, emphatic to another who is sad, cooperating, inviting friends play together, and offering help to another.

The observation was done as much as six times in Yasmin Muadz bin Jabbal Preschool. This observation taken place as long as two weeks in January 2017. The schedule arranged according to agreement reached by researcher and headmaster. This needed observation sheet with carefulness and high concentrate in order to all the children's behavior didn't be passed away. Researcher also recorded and documented with camera in order to there is no left thing.

The questionnaire divided to all preschool's parents. They were given a week to submit it back again. This let the parents to fill all the questions at home so that they can answer honestly and there was no affection from others. Children in the current study observed at different time as long as one month. In other hand, the researcher also have an interview with the teacher about the Researcher came to the school in the morning when the children started their daily activities at school and join class activity until lunch time arrived.

Analyzed

The questionnaires had been given to 61 parents, but just 34 parents had gotten it back to school. Therefore, only 34 students who will be analyzed and correlated with authoritative parenting style. Data which had been collected were analyzed by using SPSS. As for convenient analysis and understanding, authoritative parenting style has been divided in three categories, "low" (score 34-56), "middle" (score 57-79), and "high" (score 80-102). 


\section{FINDINGS AND DISCUSSION}

In this study, 34 parents was examined. The result of the correlation analysis is presented in Table 2 .

Table 2. Correlation Analysis Result

\begin{tabular}{|ll|r|r|}
\hline \multicolumn{1}{|c|}{ Correlations } \\
\hline & $\begin{array}{l}\text { Authori } \\
\text { tative }\end{array}$ & \multicolumn{1}{|c|}{$\begin{array}{l}\text { Prescho } \\
\text { nl'c }\end{array}$} \\
\hline Authoritati & Pearson Correlation & 1 & -202 \\
ve & Sig. (2-tailed) & & .251 \\
& N & 34 & 34 \\
\hline Preschool's & Pearson Correlation & -.202 & 1 \\
Prncnrial & Sig. (2-tailed) & .251 & 34 \\
& N & 34 & \\
\hline
\end{tabular}

According to the result presented in Table 2, there isn't a significant positive correlation between authoritative parenting style and preschool prosocial behavior $($ Sig. $=0.251,>0.05)$. This correlation indicates that authoritative parenting style do not affects prosocial behavior.

This study suggests propositions on empirical evidence of parenting style on preschool prosocial behavior. It is suggest that external factor influence the processes of prosocial development. Contrast in fact, this study proven that authoritative parenting style did not affect preschool prosocial behavior. It means that there were another factor that affect preschool prosocial behavior more significant. Classroom management by teacher, peer acceptance, child's mood, and feeling of children can be alternative factors which affect it.

First, teachers and classmates have the potential factor to promote the prosocial behavior (Wentzel, 2016) They can help children to communicating norms and expectations for positive behavior, creating emotionally positive classroom environments, and help children scaffolding the use of effective social cognitive and self-regulatory skills. Peers help children to model what appropriate behavior that can be accepted by another and reputed as group norms. So, children feel comfort to socialize with friends.

A study indicate that teachers manage misbehavior by developing routines activity and reinforcing rules which has obtained (Eleftheria, Kafenia, \& Andreou, n.d.). They combine the non-punitive and punitive practice to control children behavior. The non-punitive practice such as establishing and re-establishing rules, encourage children to be responsible, discuss a behavior topic, and concern for emotions or situation. For punitive practice, they use verbal reprimands and other aggressive strategies to keep children's behavior. Improving positive classroom management practice is one of the way to encourage prosocial behavior.

In the classroom setting, teachers can helps children develop prosocial behavior through modelling the desired behaviors, setting up situations that require cooperation, and suggesting specific ways that children can be cooperative or helpful with another (Brewer, 2007). Teacher can provide some play equipment which can be used for more one child such as telephones, jump ropes, and board games. Teacher can model how to show empathy and care for another hurt or sad by discussing it with children. Children also need model how to develop verbal skill by providing them to say in an interactions. How to ask to friends or adult, asking help, offering help, say thank you, say sorry, say excuse me can be directed by teacher. How to be cooperative when building block construction play is also model for children to connect prosocial behavior.

Cooperative, tutoring, and counseling are methods encouraged by teacher to enable peers to be supportive of one another (Berns, Roberta M, 2010). When children interact, they discover the distinguishing between theirs opinion and peer's. They try to reorganize cognitive structure to fit it. 
Expert peer can serve as mentors, models, or tutors. Teacher must guide and provide collaborative activities, teaching social skill, and problem solving skill.

Second, the quality of teacher-child relationship also has been affected to children's prosocial behavior (Badalà, Nouri-mahdavi, \& Raoof, 2008). When teacher-child relationship was close, children were reported as more to behave prosocial compare with when it far. They can make warmth relation to discuss, play, and share what their feel and interest so that teacher know well the children's needs. Having a close teacher-child relationship encourage the quality of child's experience in preschool by enhancing individual attention and providing a more maximum learning setting. But if teacher-child relationship had conflictive, children likely to behave more aggressively and less prosocial. Aggressive behavior was negatively associated by peers and others.

Third, even prosocial behavior first become evident in children of about two up three years interest in playing with other children arises (Boyd \& Bee,2009), not all children do like that because it depend on their moods and feelings. Sometime when another peer gives help, he or she may be angry. He want do all the activity by him. Research findings by (Blair, Denham, Kochanoff, \& Whipple, 2004), emotion regulation related to problem behavior and prosocial behavior. Emotion can cause children less cooperative to have learning experience with peers. They can less interest in and motivation for school success. Children who less interest to build interact with another, they can't develop or learn how to be prosocial. Teacher and parents can promote preschoolers' emotion understanding by exposing them to feeling every word spoken, understanding and utilizing these words to label effect in themselves and others, and recognizing that actions can cause emotion effectively.

\section{CONCLUSION}

Sig. $=0.251$ show that there is no significant realtion between authoritative parenting style and preschool prosocial behavior. This result of this study is also meaningful because it shows that alternative factors are might affect prosocial behavior such as teacher-classmates, teacher-child relation, and children's moods and feelings. Based on the present study result, it can be suggested that teacher also have proportion to develop prosocial behavior.

\section{ACKNOWLEDGEMENTS}

I wish to express my eternal gratitude to God for providing me with outstanding university within STAINU Purworejo. Their guidance and motivate were paramount to completion of this study. Special thanks to Mrs. Daryati, Mrs. Sukardi, Hendra Gunawan who are always supporting, belief, and giving blessing me to take more responsibility. I also wish to express my gratitude and appreciation to my colleagues who supports this writing.

\section{REFERENCE}

Badalà, F., Nouri-mahdavi, K., \& Raoof, D. A. (2008). NIH Public Access. Computer, 144(5), 724-732. https://doi.org/10.1038/jid.2014.371

Berns, Roberta M. (2004). Child, Family, School, Community Socialization and Support. Sixth Edition Belmont: Wadsworth/Thomson

Berns, Roberta M. (2010). Child, Family, School, Community Socialization and Support. Eight Edition. New York: Cengage Leaning

Biddle, K. A. G, Nevarez, A.G, Henderson, W.J.R, \& Kerrick, A.V. (2014). Early Childhood Education Becoming a Professional. London: Sage 
Blair, K. A., Denham, S. A., Kochanoff, A., \& Whipple, B. (2004). Playing it cool: Temperament, emotion regulation, and social behavior in preschoolers. Journal of School Psychology, 42(6), 419-443. https://doi.org/10.1016/j.jsp.2004.10.00 2

Boyd, Denise \& Bee, \& Helen. (2009). Lifespan Development Fifth Edition. Boston: Pearson Allyn and Bacon

Brewer, J.A. (2007). Introdcution to Early Childhood Eduucation. Sixth Edition. USA: Pearson

Carlo, G., Mestre, M. V., Samper, P., Tur, A., \& Armenta, B. E. (2011). The longitudinal relations among dimensions of parenting styles, sympathy, prosocial moral reasoning, and prosocial behaviors. International Journal of Behavioral Development, 35(2), 116-124.

Dowling, M. (2014). Young's Children Personal, Social, and Emotinal Development $4^{\text {th }}$ Edition. London: Sage

Dunfield, K. A., \& Kuhlmeier, V. A. (2013). Classifying prosocial behavior: Children's responses to instrumental need, emotional distress, and material desire. Child Development, 84(5), 1766-1776. https://doi.org/10.1111/cdev.12075

Eleftheria, B., Kafenia, B., \& Andreou, E. (n.d.). Classroom behavior management practices in kindergarten classrooms: An observation study ., 93-107.

Hannon, E. (2015). The effects of positive reinforcement using a group token economy system to increase prosocial behavior in an inclusive early childhood classroom (Order No. 1586935). Available from ProQuest Dissertations \& Theses Full Text: The Humanities and Social Sciences Collection. (1678090053). Retrieved from

http://search.proquest.com/docview/16 78090053 ? accountid $=25704$

Holden, George W. (2010). Parenting: A Dynamic Perspective. Los Angeles: SAGE

Knafo, A., \& Plomin, R. (2006). Parental discipline and affection and children's prosocial behavior: Genetic and environmental links. Journal of
Personality and Social Psychology, 90(1), 147-164. https://doi.org/10.1037/00223514.90.1.147

Lai, F. H. Y., Siu, A. M. H., \& Shek, D. T. L. (2015). Individual and Social Predictors of Prosocial Behavior among Chinese Adolescents in Hong Kong. Frontiers in Pediatrics, 3(May), 1-8. https://doi.org/10.3389/fped.2015.0003 9

Mena, Janet Gonzales \& Eyer, Dianne Widmeyer. (2001). Infant, Toodler, and Caregivers. USA: Mayfield Publishing Company

Miller, darla Ferris. (2010). Positive child guidance. London: Cengage

Muhtadie, L., Zhou, Q., Eisenberg, N., \& Wang, Y. (2013). Predicting internalizing problems in chinese children: The unique and interactive effects of parenting and child temperament. Development and Psychopathology, 25(3), 653-67. doi:http://dx.doi.org/10.1017/S0954579 413000084

Robinson, C. C., Mandleco, B., Olsen, S. F., \& Hart, C. H. (2001). The Parenting Styles and Dimensions Questionnaire (PSDQ) In: Perlmutter BF, Touliatos J, Holden GW, editors. Handbook of family measurement techniques: Vol. 3. Instruments \& index.

Santrock, John W. (2007). Perkembangan Anak (Child Development). Eleventh edition Volume 1 Translated by Mila Rachmawati \& Anna Kuswanti. Jakarta: Erlangga

Scarlett, W.G, Ponte,I.C, \& Singh, J.P. (2009). Approaches to Behavior and Class Management. London: Sage

Sunal, Cyntia S. (1990). Early childhood social studies. Columbus: Merrill Publ.

Wentzel, K. (2016). Prosocial Behaviour and Schooling, 1-5. 